\title{
Pedagogies for peacebuilding in higher education: How and why should higher education institutions get involved in teaching for peace?
}

\author{
Juliet Millican ${ }^{1}$ (D) - Larisa Kasumagić-Kafedžić ${ }^{2}$ (D) - François Masabo ${ }^{3}$ (D) \\ Mónica Almanza ${ }^{4}$
}

Published online: 27 June 2021

(c) UNESCO Institute for Lifelong Learning and Springer Nature B.V. 2021

\begin{abstract}
This article makes the case for why higher education institutions should take the teaching of peacebuilding seriously. It is co-authored by a team from four countries (Bosnia and Herzegovina, Rwanda, Colombia and the United Kingdom) who were involved in a small international research project looking at "Pedagogies for Peacebuilding". Together they are trying to answer questions about the legitimacy of bringing these discussions into higher education and lecturer/student relationships. The authors discuss the spaces in which peacebuilding can be usefully considered within higher education curricula; the significance of higher education in helping young people develop habits of peace; and how the citizens and leaders of the future might be helped to understand the meaning and importance of peacebuilding. In the course of their argument, the authors consider the intention and impact of different pedagogical approaches.
\end{abstract}

Keywords pedagogies $\cdot$ peacebuilding $\cdot$ higher education $\cdot$ civic engagement

Juliet Millican

J.Millican@associate.ids.ac.uk

Larisa Kasumagić-Kafedžić

larisakasumagic@yahoo.com; larisa.kasumagic@ff.unsa.ba

François Masabo

masabofr@yahoo.fr

Mónica Almanza

mi.almanza1135@uniandes.edu.co; monicalmanza3@gmail.com

1 Institute of Development Studies, University of Sussex Campus, Brighton, UK

2 University of Sarajevo, Sarajevo, Bosnia and Herzegovina

3 University of Rwanda, Kigali, Rwanda

4 University of Los Andes, Bogotá, Colombia 


\section{Résumé}

Pédagogies de consolidation de la paix dans l'enseignement supérieur : comment et pourquoi les établissements d'enseignement supérieur devraient-ils se consacrer à l'enseignement pour la paix ? - Cet article explique pourquoi les établissements d'enseignement supérieur devraient prendre au sérieux l'enseignement de la consolidation de la paix. Il a été coécrit par des auteurs de quatre pays, de BosnieHerzégovine, du Rwanda, de Colombie et du Royaume-Uni, qui ont participé à un petit projet international de recherche sur les «pédagogies de consolidation de la paix ». Ensemble, ils se demandent s'il est légitime de faire entrer ces débats dans l'enseignement supérieur et les rapports enseignants/étudiants. Les auteurs évoquent plusieurs thèmes : les espaces du curriculum de l'enseignement supérieur pouvant se prêter à une réflexion sur la consolidation de la paix, la portée de l'éducation pour aider les jeunes à développer des habitudes de paix et les moyens par lesquels on pourrait aider les citoyens et leaders de l'avenir à comprendre la signification et l'importance de la consolidation de la paix. Au fil de leur argumentation, ils examinent l'intention et l'impact de différentes approches pédagogiques.

\section{Resumen}

Pedagogías para la construcción de paz en educación superior: Cómo y por qué la educación superior debe involucrarse en la enseñanza para la paz? -El presente artículo analiza por qué las instituciones de educación superior deberían tomar en serio la enseñanza en construcción de paz. Es un escrito en coautoría con un equipo de cuatro países (Bosnia y Herzegovina, Ruanda, Colombia y el Reino Unido) que participaron en un pequeño proyecto de investigación internacional sobre "Pedagogías para la construcción de paz". Juntos tratan de responder a preguntas sobre la legitimidad de llevar dichas discusiones a la educación superior y a las relaciones profesor-estudiante. Los autores discuten los espacios en los que la construcción de paz puede ser útil dentro del currículo de educación superior; la importancia de la educación superior para ayudar a los jóvenes a desarrollar hábitos de paz; y cómo se podría ayudar a los ciudadanos y líderes del futuro a comprender el significado y la importancia de la construcción de paz. En el curso de su argumentación, los autores consideran la intención y el impacto de diferentes enfoques pedagógicos.

\section{Introduction}

Why should higher education institutions, traditionally dedicated to the neutral study of specific discipline areas, get involved in teaching peacebuilding, moral education or citizenship? How might their lecturing role be changed, compromised or challenged when discussing the messy issues of human values, beliefs and emotions? This article begins by exploring the different literatures on peace and conflict and their relation to experiential and affective pedagogies. We also look at literature on civic and citizenship education, and on violence and memory in relation to higher education curricula and how they are delivered. We recognise that higher education could play a greater role institutionally in addressing issues of peace and conflict, 
but note that this is outside the scope of this article. Here, we look specifically at issues of teaching and pedagogy in an attempt to develop a framework that makes conceptual and practical sense.

We have been influenced by John Paul Lederach's notion of a conceptual framework which, rather than providing a rigorous theoretical scheme related to peacebuilding (Lederach 2005), offers a set of ideas and analytical lenses that suggest how conflict transformation can be understood and shows how features and components of peacebuilding as a social process are defined and interrelated and how they interact. We discuss how such concepts might most effectively be learned, and make the case for how and where such pedagogies might be introduced into the processes of teaching and learning in different disciplinary areas.

\section{Why teach peacebuilding in higher education?}

In the past two decades there has been a growing interest in the field of education and conflict (Bush and Saltarelli 2000; Davies 2004; Novelli and Cardozo 2008; Pherali 2019; Davies 2010; Mundy and Dryden-Peterson 2011; Novelli and Smith 2011). However, most of this has focused on formal schooling and the teaching of children. It is only in the last decade that the role of higher education in the process of socialisation and reconstruction in relation to conflict has begun to enter the literature (Bergan and Van't Land 2010; Barakat and Milton 2015; Omeje 2015; Milton and Barakat 2016; Millican 2017; Pacheco and Johnson 2017; Milton 2018).

Earlier research on education and peacebuilding drew attention to a number of crucial factors affecting all sectors. Kenneth Bush and Diana Saltarelli's work on "the two faces of education in ethnic conflict" (Bush and Saltarelli 2000) indicates how education can either promote or undermine understanding, equality and social cohesion, depending on what policies and approaches are adopted. This is as true for higher education as it is for schooling (Millican 2017). The theoretical framework of Mario Novelli et al. (2015) on the "4Rs in conflict-affected contexts" identifies Redistribution, Recognition, Representation and Reconciliation as necessary elements for building sustainable peace. All of these can be addressed in higher education curricula and are relevant to the way university lecturers teach.

In recent publications, Davies (2016) has begun to question the very notion of "peace education", asking whether any country can truly be referred to as "postconflict" and whether locating learners as responsible for peace is not itself problematic. While the habits of democracy can be taught and learned (Millican 2014a), and young people can be introduced to the triggers behind conflict, its structural and political causes remain complex. "Peace education" or "peace pedagogies" can therefore appear to be loaded terms. Indeed, many countries experiencing ongoing tensions, violence or occupation avoid using the terms "conflict" or "peace". Davies (2016) suggests that it may be more useful to talk about managing conflict, reducing violence, and cultivating a heightened awareness of the underlying causes of inequality, discrimination and marginalisation. Lederach (2005) uses the term "conflict transformation" rather than "conflict cessation" or "peacebuilding". 


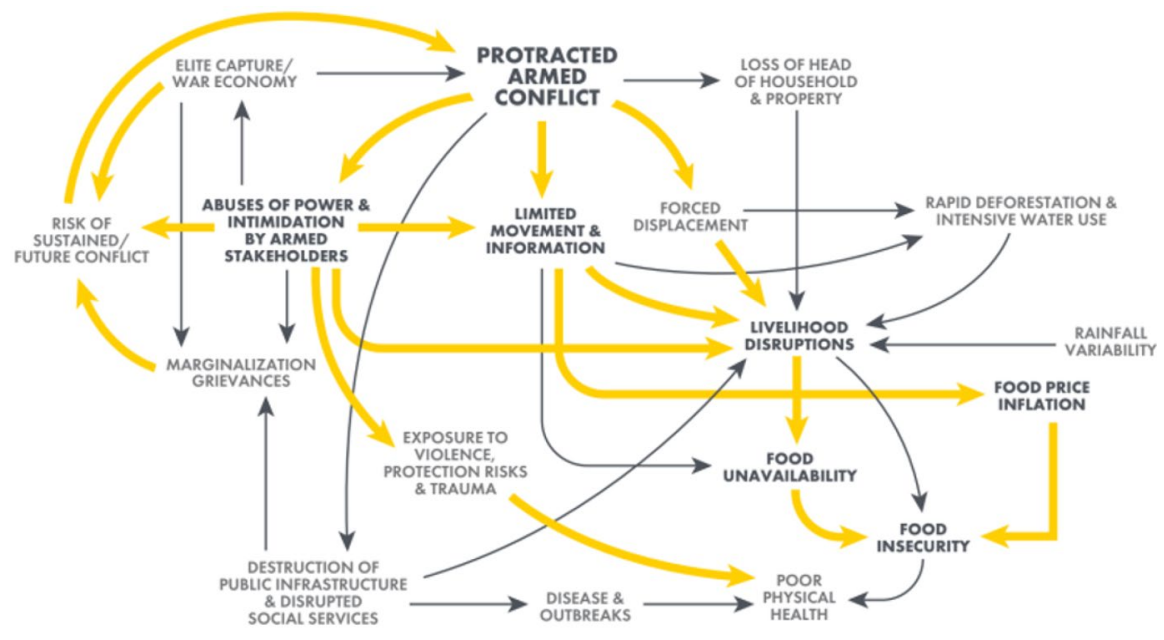

Fig. 1 Conflict is better understood as a system rather than an event. Source: Whitaker (2020)

In research into climate and conflict, Whitaker (2020) described armed conflict as a system rather than an event, illustrating the interconnection of the various factors lying behind armed response. Her illustration of these factors (Figure 1) suggests the need for an integrated systems response, bringing together the best thinking and practice from a range of different perspectives to the analysis of conflict.

Universities are complex institutions with specialists in many areas, invariably separated into different disciplinary silos. A cross-institutional or interdisciplinary response, in which researchers, practitioners and students from all disciplines work together to address the triggers behind conflict, may be the most viable approach to managing and minimising conflict in the longer term. We need a structured, systemic approach to recognising the existence of conflict and the responsibility of higher education to address it.

Within current higher education curricula, spaces for discussing inequality, difference, conflict and cohesion can be found in courses on civic education, citizenship, ethics and democracy, as well as in specific courses on peacebuilding. All professional and vocational courses contain opportunities to discuss ethics and professional practice, and to consider how contributing to peace and reducing violence might feature in fields as diverse as medicine, teaching, youth work, accountancy or business management. The British Council's Going Global Conference for Leaders of International Education held in 2013 included discussions on the role that a university can play in citizenship, democracy and peacebuilding. It acknowledged that

there is increasing interest in the role of higher education in post-conflict societies, and the potential contribution it can make to long-term peace (Stiasny and Gore 2014, p. 37, cited in Omeje 2014, p. 2).

Higher education represents an important stage in the development of a young person's future. While there are still far fewer young people in university than in 
secondary school, the numbers are growing. The number of students in higher education globally doubled between 2000 and 2014 (Roser and Ortiz-Ospina 2016; UNESCO 2017). While schools tend to attract children from similar geographical, ethnic or class backgrounds (with many still divided in post-conflict areas), universities bring together young people from diverse geographical regions and ethnic backgrounds. Even without structured and facilitated conversations, higher education provides countless informal opportunities for students to question the values and practices of their homes and families and begin to make their own decisions as adults. Coupled with an environment of study, reflection and activism, university is a place where many begin to construct a separate identity for themselves. As such, it presents a vital opportunity to address the transformation of conflict.

Traditionally, however, higher education has been content-focused, drawing on pre-agreed canons of knowledge delivered via a didactic approach. The lecture format, supported by reading lists and objectively written essay assignments and constrained by the positivism of the "hard" (natural) sciences, offers limited spaces for discussing values, ideas, beliefs, and the messiness of human responses. Bourner (1998) makes the case for the importance of including personal development and social involvement within university curricula, linking what he calls the "inner knowledge of self" with the "outer knowledge of the world" and valuing the development of inner skills and self-knowledge in all forms of professional development. Other higher education practitioners have looked at the importance of affective learning in higher education (Beard et al. 2007; Shephard 2008; Evans et al. 2013; Millican 2014b) and argued for its inclusion. We recognise that this will be unfamiliar territory for many higher education teachers. Based on our own involvement in a small, international research project looking at "Pedagogies for Peacebuilding", we argue that an understanding of the different domains of learning constitutes good pedagogy and provides an ideal basis on which issues of peacebuilding and conflict resolution might be addressed.

\section{Understandings of and approaches to conflict and peacebuilding}

For the purposes of this article, we use the term "conflict" to refer to situations where feelings, thoughts and actions revolve around confrontation, hostility and disagreement in ways that are protracted rather than momentary. While conflict is not in itself negative or destructive, and indeed is often essential to transformation and change, the actions associated with its expression, prevention, resolution or

\footnotetext{
1 "Peacebuilding Pedagogies" was an international project collaboration between Bosnia and Herzegovina, Rwanda, Colombia and the UK funded by a Global Challenges Research Fund (GCRF) Networking Grant awarded through the British Arts and Humanities Research Council (AHRC). The project was launched in January 2019 and ended in December 2020. The project team, which included all four authors of this article, comprised academics from the Sarajevo Peace Hub (University of Sarajevo), the University of Rwanda (Kigali), Los Andes University (Bogotá), the Institute of Development Studies (University of Sussex, Brighton), and the University of the Arts (London). For more information about the project, see https://gtr.ukri.org/projects?ref=AH\%2FS003908\%2F1 [accessed 9 April 2021].
} 
transformation can be violent or non-violent, physically or psychologically. Similarly, "peace" can be positive (indicating arrival at a state of agreement and willingness to move) or negative, involving unexpressed ongoing hostilities and the cessation of violence without agreement. While a negative peace may be preferable to sustained violence, it offers little chance of recovery, socially, emotionally or economically. Pacifism can also include the management of conflict with a commitment to non-violence. It is active (Webel and Galtung 2007), managing conflict rather than avoiding or endorsing it. Galtung (1969) identifies the various stages in the process towards peace and distinguishes between what he calls "positive peace" and "negative peace". Negative peace, or ceasefire, is the absence of direct violence or war between different factions/states. Positive peace is an absence of structural violence (unintended policy which causes extreme suffering) and economic exploitation. Galtung argues that peace cannot fully be declared if the aspects of inclusion (gender, ethnicities and families) are not addressed.

The term "peacebuilding" is relatively new to the literature. Boutros BoutrosGhali (former United Nations Secretary-General) defines it as one of the four important responsibilities of the United Nations (UN) in relation to conflict, following on from preventive diplomacy, peacemaking and peacekeeping. For Boutros-Ghali, peacebuilding is about sustaining peace once it has been established. Lederach defines peacebuilding more broadly, as a comprehensive concept that encompasses, generates and sustains the full array of processes, approaches and stages needed to transform conflict towards more sustainable, peaceful relationships. He understands peace as a dynamic social construct that requires a process of building, investment, design and labour, with time needed to lay its foundations, build it up and continually maintain it (Lederach 2005).

Both thinkers agree that peacebuilding is significant not only after the cessation of violence but over the whole conflict cycle, during the build-up of hostilities and breakdown of trust in democratic structures, and across the various individual and group interactions that contribute to both conflict and the maintenance of relationships in any community or society.

Peacebuilding involves working towards an environment of inclusivity based on social justice and equity. In our own debates, we have spoken of "the activism of pacifism" (internal dialogue), and of working to reduce or manage violence rather than deny the existence of conflict. Young people need strategies to understand and work through conflict in order to develop more positive outcomes for all parties. We should see conflict as an ongoing fact of life that requires a combination of personal skills and conceptual understanding to manage effectively. We need to infuse traditional taught curricula with active pedagogies that interact with civil society and build peace within it according to each society's particular history and context.

Richmond (2011), critiques top-down neoliberal approaches to peacebuilding within international relations in favour of more locally-driven solutions. There are many opportunities for both academics and students in universities to identify and work with these. Omeje (2014) and Francis (2008) urge universities across the African continent to play a greater role in peacebuilding with an African or local approach. For these localised approaches to work, they need to be developed in context by those with both conceptual knowledge and local connections 
and understanding. Sensitive issues can easily be misrepresented or misunderstood by outsiders. While national and international organisations have begun to search for indigenous mechanisms to promote peace and social cohesion, and often recommend involvement in and ownership of peacebuilding processes by local people, these have not really impacted on the way peacebuilding is taught. Western approaches still dominate university curricula, despite the fact that imported liberal notions of education can be in direct conflict with local attitudes or subjects. Grassroots stakeholders are often misrepresented. "Local" is confused with "national", civil society is wrongly viewed as grassroots, and the terms "grassroots" and "civil society" are used interchangeably. If not handled sensitively, such language can further incite violence between students or risk universities being targeted as radical institutions. In order for university curricula to properly understand and work with locally-generated approaches to peacebuilding and conflict transformation, they must be closely connected with research and committed to developing and adapting within a contextual framework.

\section{Does pedagogy matter?}

In our experience, how something is taught is just as important as what is being taught. Top-down, traditional or content-based pedagogies tend to privilege certain forms of knowledge and to promote a single academic truth. When such truths are imported, they can appear even more alien in the contexts in which they are taught. Teaching from an assumed position of power can reinforce the power relationships and inequalities that underlie conflict. Schön identifies the important difference between "the idea of rigorous professional knowledge", which he argues is based on a kind of instrumental rationality, and an "awareness of indeterminate, swampy zones of practice" beyond the capacities of technically derived solutions. The latter, in his view, contain the most pressing human problems (Schön 1987, p. 3).

In our own work, we feel that it is as important to acknowledge the complexity of conflict and the "messiness of human response" as it is to recognise the existence of relative truths. Teaching about plurality and diversity lacks congruence if that diversity is not reflected in classroom or lecture hall relationships. Lecturers need not only to recognise the existence of different forms of knowledge; they need to acknowledge it in their interactions with learners if they are to effect any lasting change. Betts Fetherston and Rhys Kelly (2007) suggest that for students to live as well as learn change,

transformation in teaching and praxis needs to be employed through a finely balanced ongoing awareness and interaction at the boundaries of discursive knowings where complexities are most intense so to avoid "doing harm" but also "doing good" (Fetherston and Kelly 2007, p. 282).

Education has become increasingly competitive as a result of well-publicised international comparisons and ratings. Meanwhile, a global preoccupation with economic output and competition has elevated the importance of language, 
mathematical and scientific knowledge over social, personal, spiritual, cultural, arts and humanities education (see OECD 2014).

The Freirean concepts of "critical pedagogy", "praxis" and "pedagogy of the oppressed" (Freire 1970) have a lot to offer to the teaching and learning of conflict transformation. Paulo Freire worked mainly in non-formal education. In his work, he advocates dialogue and equality of relationship and respect in teacher-student interactions. He critiques the "jug and mug" form of pouring content into empty heads, often adopted in structured, content-heavy university programmes where lecturers are expected to speak and students to listen. Freire's notion of praxis - action followed by reflection followed by action - brings together cognitive, emotional and reflective thinking. He suggests that it is "our responsibility to teach people to imagine a better way so that they can shape their future and thereby become more human" (Freire 1998, p. 94). Developing imagination and supporting creativity cannot be done through top-down knowledge transfer, hence the need for a new pedagogy and a new dialogic relationship between teacher and student:

teaching cannot be a process of transference of knowledge from the one teaching to the learner. This is the mechanical transference from which results machinelike memorization ... Critical study correlates with teaching that is equally critical, which necessarily demands a critical way of comprehending and of realizing the reading of the word and that of the world, the reading of text and of context (ibid., p. 22).

Key concerns for Freire are inequality, resistance to oppression, and the ability to understand and take action in the world. He writes primarily about the issues underlying conflict rather than conflict itself. However, he does not ignore the existence of conflict or its importance in challenging the status quo and working for change. $\mathrm{He}$ is concerned with the human tendency to judge others and group around shared identities, and with the need for tolerance and humility. By allowing for difference and breaking down social barriers, Freire questions preconceived notions of the "inferior" or "superior" other, an important element in peace education programmes.

Critical pedagogy theorist Giroux discusses the "pedagogy of responsibility": the importance of educating young people simultaneously both for their professional future and for critical citizenship. In his view, teaching must go beyond the delivery of knowledge to an interrogation of knowledge, values and experiences through different social practices and settings. This needs to include an understanding of how:

the political becomes pedagogical, particularly in terms of how private issues are connected to larger social conditions and collective forces - that is, how the very processes of learning constitute the political mechanisms through which identities are shaped and desires mobilized, and how experiences take on form and meaning within and through collective conditions and those larger forces that constitute the realm of the social (Giroux 2004, p. 63).

Freire, Giroux and Lederach all advocate for a contextual pedagogy that relates to student experience, the heart as well as the head. All three scholars emphasise 
the importance of image, metaphor and story to help re-examine history and lived experience. As such, they have a lot to offer to university educators and those who are training the professionals of the future, particularly when it comes to dealing with the tensions that underlie conflict and violence. Their task is to develop individuals who, alongside knowing how to access and use positivist knowledge, can also recognise the value of different forms of knowledge; individuals who can engage in dialogue with others, reflect on and build relationships, identify opportunities, recognise complexity, and imagine a different future. Pedagogy matters.

\section{Situating peace and conflict in higher education curricula}

Universities in places with a history of conflict often include research centres where conflict is studied (e.g. Belfast, Bradford, Beirut, Birzeit), but there are fewer examples of active attempts to teach conflict resolution across the curriculum. Modules focused on peace education (Novelli et al. 2015) differentiate between a focus on changing minds and behaviour, and an emphasis on more structural issues of governance, access, quality and provision; between short-term educational interventions targeting particular conflict and security-related phenomena and specific thematic interventions supporting reintegration, economic growth and social cohesion. Such approaches often include developing "life skills" such as negotiation, preventive diplomacy, emotion management and empathy, all important elements in intra- or interpersonal peace. However, they fail to address the various types of civil, cultural, environmental and global violence that take place outside of schools (Bush and Saltarelli 2000; Burstyn 2001; Harris 2004; Novelli 2016), and to assign responsibility for solving broader violence and injustice.

We feel that, while what is taught has to emerge from the local context, the how of teaching has more universal significance. Our work is informed by experience in four different university institutions: the University of Sarajevo in the Balkans, the University of Rwanda in East Africa, the University of Los Andes in South America, and the University of Brighton in Europe. Each provide different perspectives on the nature and duration of conflict and the approaches taken to address it, whilst sharing similar lessons on valuable pedagogical approaches.

Bosnia and Herzegovina is often seen as existing in a state of "frozen conflict" or negative peace. The imposition of a structural solution to violence in the form of the General framework agreement for peace in Bosnia and Herzegovina (the "Dayton Agreement") in 1995 (UN 1995) built segregation and nationalism into political structures. Many of the underlying causes of economic hardship and problems of national identity persist unaddressed in social groups. A great number of schools are divided, and some still teach children separately within one larger building. Some university programmes have students from different parts of the country studying alongside each other as equals.

Rwanda is often seen as being in a period of post-genocide recovery, with genocide prevention remaining high on political and social agendas. While the outbreak of violence between Hutus and Tutsis occurred at a similar time to the violence in Bosnia and Herzegovina, the Rwandan government has taken a proactive response, 
with a single stable government remaining in place since the genocide. Though criticised for its dominance and inflexibility, this government's recognition of the significance of gender relationships to peacetime and incorporation of large numbers of women in political power has shifted gender relationships countrywide.

Colombia has experienced a period of extended violence since the mid-1960s with conflict between government, paramilitaries, crime syndicates and guerrilla groups. Although peace dialogues took place between 2012 and 2016, these have not held. Unlike other conflicts where war is primarily between a government and an armed group, the Colombian situation involves many actors with complex ties, one of the greatest barriers to achieving any kind of agreed peace.

In the United Kingdom (UK), many people attribute peace to the economic cooperation encouraged by the European Economic Community and the removal of a hard border on the island of Ireland. The move to leave the European Union (EU) during the period 2015-2019 led to divisions at regional, local and family level, as different individuals firmly stuck to their own commitments to "leave" or to "remain". These divisions surfaced during the period of our research (January 2019-December 2020), but subsided after agreements to leave were signed and ratified in January 2020 and priorities shifted by the outbreak of the global coronavirus pandemic in March 2020. At the time of writing (April 2021) these hostilities appeared to be resurfacing as agreements over a hard border between the UK and Ireland were again in doubt.

\section{Approaches to pedagogy in different contexts}

This section discusses the different approaches to peacebuilding used by the "Peacebuilding Pedagogies" project partner universities: the inclusion of common modules that were offered in different subject areas (University of Rwanda and University of Brighton, UK), working with memory and retribution (University of Los Andes, Colombia), and introducing alternative teaching approaches into teacher training departments (University of Sarajevo, Bosnia and Herzegovina).

\section{Common cross-university modules}

The University of Rwanda takes a cross-university modular approach. All undergraduates have the opportunity to take a first year module on "Citizenship and Transformative Education" which involves reflection on key features of peacebuilding after conflict and genocide through four units:

(1) Civic education, which comprises the concepts of citizenship, state-building, identity and nation-building, and an overview of the history of Rwanda.

(2) The legal system in Rwanda and how rights and liberties are protected.

(3) International human rights and citizenship education.

(4) Education for Peace. 
For many students, university education provides a first experience of living and studying with people from a different ethnic group, although in Rwanda different ethnic groups will have lived together in the same villages all their lives, attending the same schools, churches, markets, etc. Nonetheless, post-genocide reconstruction requires multi-dimensional approaches and strategies to restore a sense of social cohesion and redress exclusion and inequalities (Murithi 2008, p. 17) in addition to just bringing groups of young people to work together.

Like many African conflicts in the post-Cold War era, divisions are deeply rooted in society (Omeje 2008, p. 68). The module reviews the history of Rwanda and its periods of segregation and discrimination, demonstrating that living together is still possible despite the suffering endured on both sides. Students are asked to take into consideration the separate experiences and memories of war and genocide shared within both groups. Having students share experiences in the same room is a powerful step towards this.

The pedagogical principle of empathy (Jones and Augustine 2015) discussed earlier in this article is close to the philosophy of "ubuntu" and underlies many traditional African approaches to dispute resolution (Omeje 2008).

Ubuntu is a humanistic philosophy (which has no English synonym) and connotes "collective personhood", and is best captured by the Zulu maxims: "a person is a person through other persons"; "my humanity is inextricably tied to your humanity". It is an overarching, multidimensional philosophy that invokes the idiom and images of group cooperation, generosity, tolerance, respect, sharing, solidarity, forgiveness and conciliation (ibid., p. 89).

Rebuilding understanding and connections with a group that has been framed as "the enemy" requires the development of empathy: being aware of and sensitive to the motivations of "others" and their capacity to reflect on their thoughts and feelings, without necessarily accepting or agreeing with them. An empathic response can be embedded into the reading of any text by requiring students to try to relate to perspectives and approaches that might be vastly different to their own. It entails looking without bias, suspending personal judgement and approaching something with a willingness to understand - a key element of higher education learning.

In the University of Brighton in the UK, a cross-university module supports the active development of empathy as part of an experiential project managed in partnership with local community-based organisations. ${ }^{2}$ The approach draws on the concepts of service learning (Eyler and Gyles 1999) and student-community engagement (Millican and Bourner 2014). Students are placed with civil society organisations as part of their studies, to work with different marginalised groups and people. Students are assessed through their reflections on this experience and its significance. They are invited to deconstruct the causes of inequality or marginalisation underlying conflict, and to meet and build relationships with people whom they may not otherwise have encountered.

\footnotetext{
${ }^{2}$ For more information on the University of Brighton's Community University Partnership Programme (CUPP), see https://www.brighton.ac.uk/community-partnerships/index.aspx [accessed 9 April 2021].
} 
Modules like these encourage the development of democratic principles and provide an alternative to the (abstract)

mode of knowing itself [that] breeds intellectual habits, indeed spiritual instincts, that destroy community [, where w]e make objects of each other and the world to be manipulated for our own private ends" (Zlotkowski 2007, p. 42).

The UK model has also been adapted and introduced into universities in Bosnia and Herzegovina, Senegal, Iraq and the North and South of Ireland. The Talloires Network in Tufts University in the United States, ${ }^{3}$ formed to promote university social engagement globally, works with 417 institutions in 79 countries, many of which follow socially engaged approaches to learning.

Partnering with civil society organisations and identifying local social change projects, possibly through tutors already committed to this work, is an effective way to create safe and meaningful engagement opportunities for students. Undergraduates contribute with practical energy and involvement, while postgraduate or masters students are often able to complete discrete tasks on behalf of an organisation or group, such as an evaluation or a piece of structured research (see Millican and Bourner 2014). Projects might be located in peacebuilding organisations, but other kinds of organisations, such as prisons, kindergartens, disabled peoples' organisations and primary schools, offer the opportunity for students to transcend difference and work with those whose views, attitudes and life experience may be vastly different to their own. In environments where students might be uncomfortable in crossing ethnic and cultural divides, confronting other forms of difference and moving out of their comfort zone helps to develop valuable interpersonal skills and confront students' own forms of separation and bias.

It is important that projects are seen as mutually beneficial, valuing different kinds of knowledge and encouraging students to recognise that they will probably gain far more than they give by learning to question inequalities and marginalities. Projects that are linked to students' subject areas either directly (e.g. criminology students working with prisons) or indirectly (e.g. teachers working with children outside of a school environment) help connect to existing interests and passions while enabling students to challenge their values and views of the world.

\section{The pedagogy of memory and retributive and restorative justice}

The Centre for Applied Ethics at the University of Los Andes in Bogotá (Colombia) works with pedagogies of memory and moral ethics, using reflection and self-knowledge to understand and deconstruct historical, cultural and personal recollections of the past. Working with personal memory carries its own risk and can bring traumatic and horrific events to the fore. Responding to these within a learning situation requires a safe environment and honest dialogue with

\footnotetext{
${ }^{3}$ Its website is at https://talloiresnetwork.tufts.edu.
} 
students on the responses such memories might evoke. Noddings (2002) writes of the need to cultivate a "culture of caring" and an empathic response to suffering. This is complicated when students share a common identity with perpetrators. One of the greatest challenges of the human condition is understanding the scope of the actions of which humans are capable and making sense of those actions when committed by others. Such processes, like those in the common modules described above, require a reclaiming of the personal in higher education work, a recognition of the fundamental humanity of others and a reconnection with empathy, acknowledging without condoning the existence of horror, fear and violence.

Pedagogies of memory provide a good starting point to developing an understanding of justice and of how the past can be used either to perpetuate and reignite conflicts, or to commemorate and compensate victims and advocate for more reflexive ways of remembering (Wagoner and Brescó 2016). Recognition of and reparations for injustices are central to the avoidance or perpetuation of violence, and a sense of justice is integral to forgiveness: "never again" is a common post-conflict refrain. Memory and its products can deepen understanding of the suffering caused by conflict and highlight the reparation practices that students can engage in to promote non-violent action.

Conflict and memory are often two sides of the same coin, which seamlessly feed into each other ... conflicts deeply mark the memories of both individuals and collectives, thereby hampering future reconciliation (Wagoner and Brescó 2016, p. 1).

An active, collaborative approach to teaching peacebuilding needs to encompass an understanding of different approaches to justice. Redistributive justice, where crime and violence are viewed as breaches of the social code requiring state intervention to change behaviour, revolves around the offender. Restorative justice, where crime and violence are seen in relation to those affected by them, revolves around the victim. Past injustices where reparation is seen as insufficient are often used as justification for current violence. Exploring what justice means in context helps take memory work from a focus on the past to a vision of the future.

Students have access to their own personal memories and to those of their family members, social groups and networks, as well as those documented in film, art and literature. Nussbaum (1997) and Rorty (1998) both advocate for the power of narrative empathy and the value of literature and cultural artefacts in peacebuilding (Hussein 2017). By analysing the meanings attributed to particular cultural objects, traditions can be critically examined, questioning the different beliefs transmitted through culture and identifying the ways in which certain groups have been devalued or discriminated against (Staub 2002). Personal and collective memories of violence, reparation and non-violence can be used as objects of study, provided that a broad repertoire of voices is involved, particularly those that have been excluded from official accounts of the past. 


\section{Working through teacher training departments}

Developing pedagogies that include the key elements of empathy, engagement and experience yet work in different educational structures is a challenge for many teacher training units, particularly in contexts where formal educational teaching remains divided, such as in Bosnia and Herzegovina. The schools in which teachers go on to work and the curricula they are asked to deliver are rarely open to diversity. Educational policies and practices have always been resistant to civic engagement or critical and transformative approaches to learning. In such contexts, university teacher training departments can play a unique role in leading the future of schooling in places deeply affected by trauma and division.

Educators in these places invariably come from communities affected by violence and have themselves experienced trauma. They are not neutral figures, without history or identity, without personal narratives of loss, shame, injustice or vulnerability, power or peacebuilding agency (Clarke-Habibi 2018). As such, they can play an active role in the reconstruction of conflict-affected societies by encouraging the trainee teachers in their own classes to discuss the impact of the conflict they have experienced on their own lives and the lives of the young people they are leading. Properly supported, they have the opportunity to reflect on the broader structural and psychological aspects of teaching for peace.

Growing up in a divided society with an overt construction of difference inherited from their parents' generation and embedded into social structures creates an automatic "other", and thus permits a level of moral disengagement and dilution of responsibility. This can lead to a gradual process of dehumanisation and the denial of human attributes to a particular ethnicity or group, helping to justify acts of violence that might otherwise appear inhuman. Many children are aware that this happened in their own families. Moving on entails reversing the beliefs and myths their families may have constructed. Educational approaches that focus on the process of re-humanisation (Gill and Niens 2014) can help with this. Recognising the other as an equal, regardless of acts they have committed in the past, redefines them as a rational being who has ideas, beliefs, opinions. While they may not share the objects and motivations of our affections, they have the capacity to share many of the same emotions. It involves not just learning about the past but actively engaging in critique of why and how the past happened, from a cognitive and a relational perspective. Formal school curricula often promote a particular narrative of the past. Helping children to question, rather than accept, this single interpretation is crucial even at a young age.

History education is recognised as a key site for constructing identity, transmitting collective memory and shaping "imagined communities". Its revision or reform is thus a complex and important part of education (Paulson 2015, p. 1). Paulson's research (ibid.) into 42 empirical studies from 11 countries found that the majority of young people learn about past conflict from a variety of sources of which school is only one, and that when the history of recent conflict is taught in school it often relies on traditional, collective memory and the unchallenged dissemination of ethno-nationalist narratives. She recommends a reform of history curricula which present recent conflict as an "active past", especially in segregated contexts such as 
Bosnia and Herzegovina. Where conflict and segregation continue to be embedded in society, history curricula are particularly controversial and rely on different interpretations and sources among different ethnic groups.

Teacher training programmes in the pre-service and in-service teacher education curricula have been slow in introducing peace pedagogies into formal teacher education. However, the University of Sarajevo is actively supporting a group of individual teacher educators who have redesigned their courses to specifically address issues in a conflict-affected society. Their revised curricula include intercultural learning, democracy and human rights education, critical discourse analysis in media, and contemporary history teaching. Promoting their learning through educational networks is an important step in taking this forward.

Davies (2017) stresses the importance of shifting from a peacebuilding approach in school education to one that stresses the management of conflict, alongside a realistic critical approach to understanding how extremism can take hold, rather than simply spreading messages of inner peace and harmony. Her recommendations are indicative of an overarching belief in the critical pedagogy approach that emerged again and again in our research: a pedagogy that questions rather than instructs, that looks for parallels, patterns and comparisons and tracks the process and system of conflict, rather than merely learning about it. Higher education institutions need to model these approaches in their pedagogies and work for their inclusion in national educational policy and formal curricula, building a strong network of universities and communities affected by violence.

\section{An international student project}

Our own cross-university "Peacebuilding Pedagogies" project included a student activity in which small groups identified significant cultural artefacts that for them transcended local divisions. The students then interviewed people of a different class, age or ethnicity about the meanings they attached to these artefacts. They tabulated and shared their results as part of a classroom exercise, which generated much discussion around the role of cultural heritage in peacebuilding and how meanings can differ between or transcend ethnic, class or generational divides. Images of the artefacts chosen by the students, quotes from the interviews and interpretations thereof were compiled into a travelling exhibition which was shown in each of the countries involved. Students said they benefited from hearing varying interpretations of what they had thought of as familiar objects, from exchanging memories with people from very different backgrounds, and from the insights they gained into conflicts elsewhere. The students hosted an international webinar to share results among themselves and draw conclusions about image, meaning and identity. ${ }^{4}$

\footnotetext{
4 Most of the project, including the exhibitions, was undertaken in 2019 and January-March 2020, i.e. before the outbreak of the COVID-19 pandemic. Webinars were a way for students in different partner countries to communicate.
} 
In sum, through our international collaboration, students from different countries and universities undertook the same project in their own localities. Photographs and findings from the different projects were exhibited together in three of the four countries. An online workshop was held in which students spoke to each other about their findings from the project and shared the histories of conflict in each country. Learning outcomes included developing skills of communication, analysis and reflection. The project showed how conflict is a fact of life in many different parts of the world, and that common patterns can be identified despite vastly different histories. Analysing a conflict in a country other than the one in which you are living helps to make these patterns clearer and to move from a personal response to a more distanced acceptance.

The case for moral, personal and experiential or engaged education in the higher education sector has been made many times in the literature (Carr and Hartnett 1996; Fitzmaurice 2008; Pickus and Reuben 2010; Zlotkowski 2007). While teaching ethics has a specific place in areas such as law, medicine, education and psychology, all disciplines involve critical thinking skills, deep analysis and the questioning of previously held assumptions. Their different perspectives contribute to a complex understanding of the management of conflict and provide opportunities for multi-, inter- and transdisciplinary ways of working. While universities aim not to teach students what to think, they are constantly concerned with educating in how to think - a crucial factor in peacebuilding (Davies 2004).

There would seem to be two tasks for education in not contributing to the essentialist identities which can be mobilized for conflict: the acknowledgement of ambiguity, complexity and hybridity within an individual self, and similarly the avoidance of stereotyped portrayals of "the other" (ibid., p. 91).

\section{A cross-cultural framework for peacebuilding pedagogies}

The pedagogical approaches discussed above can be brought together in a loose framework, indicating their importance for higher education, as shown in Table 1.

However, rather than seeing these as separate it might be more accurate to represent them as linked or nested inside each other as indicated in Figure 2. At the centre are specific peacebuilding modules that can be added in as electives or cross-university studies dealing with a considered response to the immediate context in which students find themselves. However, the approaches used in such modules can also be introduced into other subject-specific areas that enable students to understand their work or profession in its broader context. The use of memory, narrative, the arts and emotion is valuable not only in teaching moral education. It can also be effectively harnessed in sociology, international relations, languages, medicine or the sciences to explore questions of professionalism. Such approaches generally make use of a critical or reflective stance, encouraging students to converse with each other and to question themselves. Introducing elements of experiential learning, such as sending students out into the field to confront the realities of the context in which they will be working, 


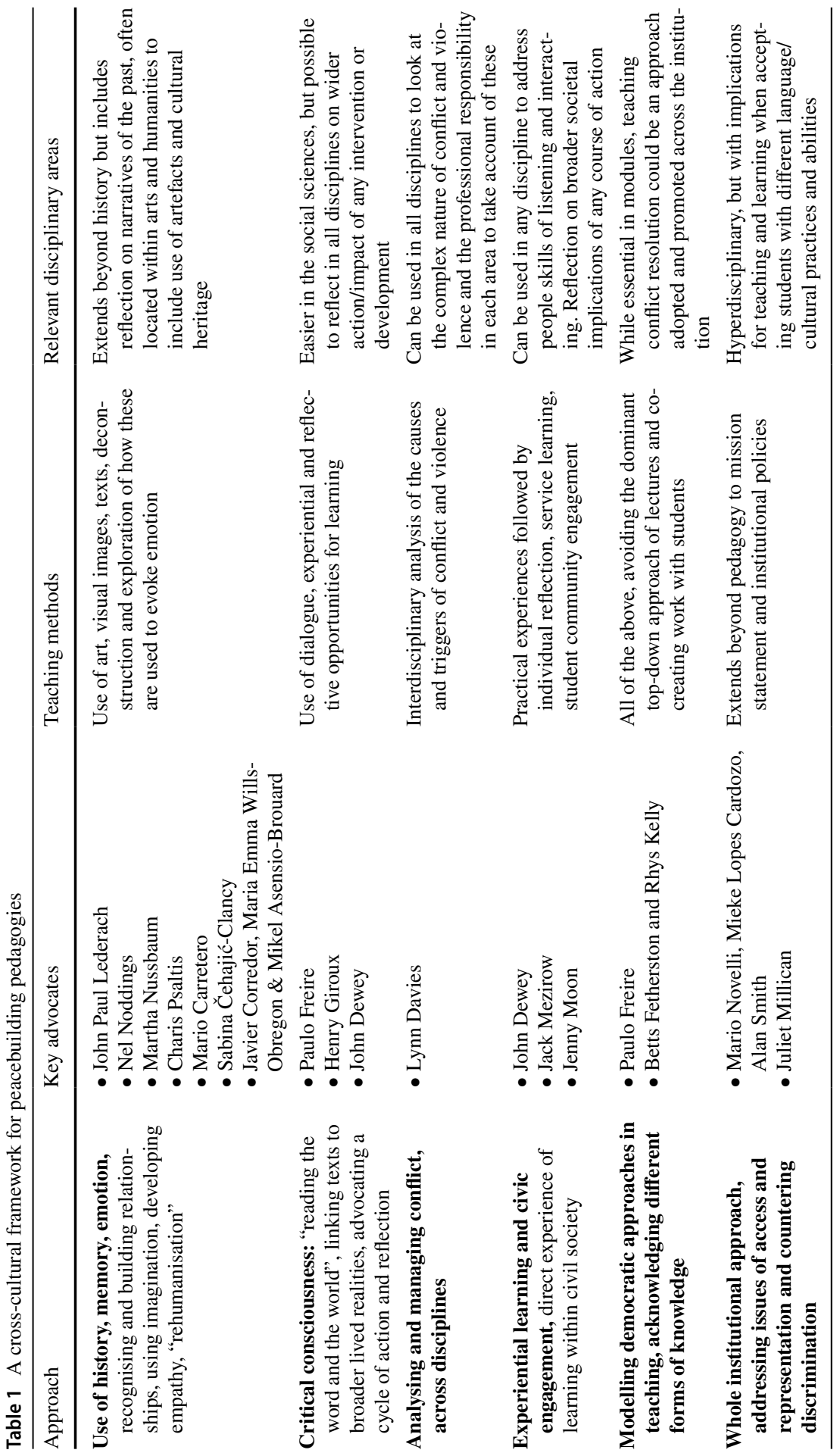




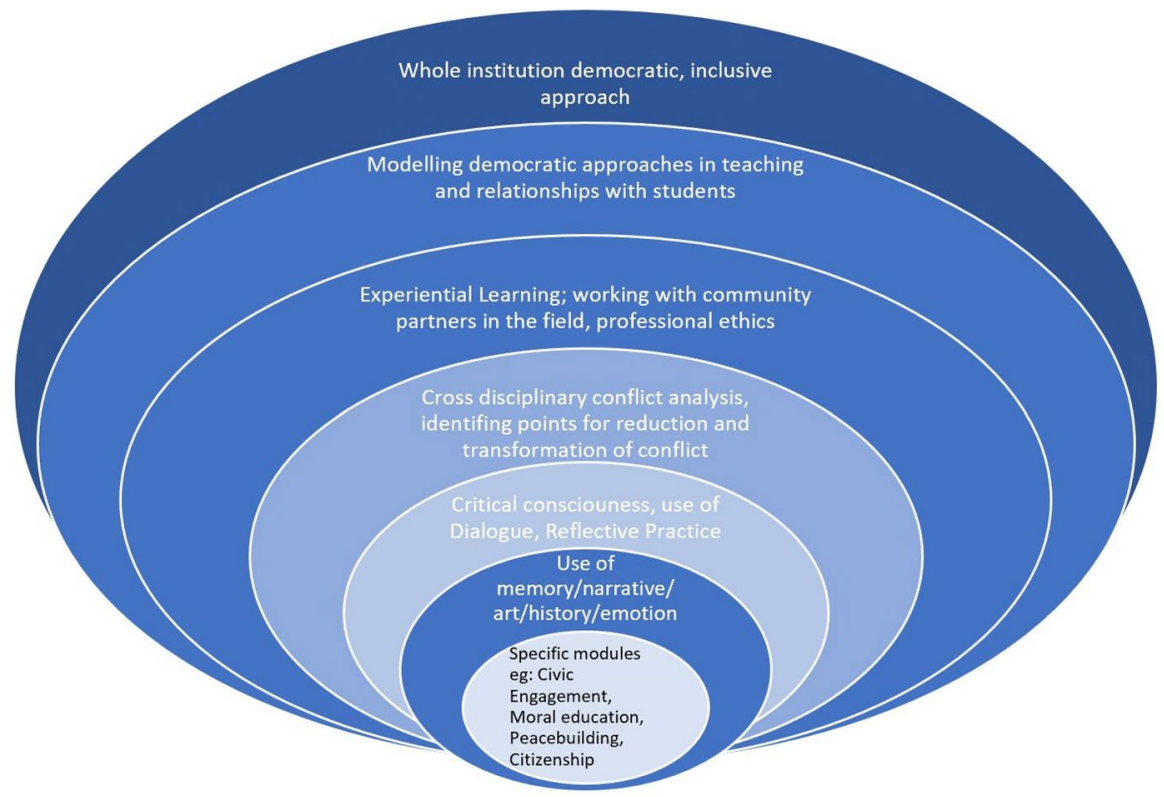

Fig. 2 Understanding peacebuilding pedagogies in a university setting

adds meaning and relevance to dialogue and reflection, while cultivating democratic and equitable relationships in the classroom encourages respect and inclusion. Finally, a cross-institutional approach in which students are given a voice in issues of governance and inclusion adds integrity to cross-institutional relationships between the university and the wider region. This can be extended beyond pedagogy to university mission statements and access arrangements to promote social mobility and address inequalities of the past.

While pedagogies are by nature rooted in particular cultural and political norms, these overarching principles seem to hold true across the different contexts in which we are working. Ultimately, they reflect the nature of being human and finding ways to manage the conflicting demands and relationships that are a fact of life for all of us. Much of the literature we have cited emphasises the emotional aspects of human experience rather than the cognitive aspects more familiar in traditional university teaching. It calls for a fundamental shift in how tutors relate to their classes. The contexts in which we are working are sensitive, and these sensitivities frame the lived experiences of our students. Davies' research (Davies 2017) in 23 countries on education and violent extremism stresses the importance of providing a critical and political understanding of conflict and engaging with counter-narratives and broader civil society. She recommends airing rather than avoiding uncomfortable truths, working with rather than ignoring present realities, and acknowledging conflict as an inescapable fact of life. The university has a responsibility to help its graduates hold these conversations and incorporate them into their everyday practices as citizens and professionals. 
Acknowledgements This research was funded by a Global Challenges Research Fund (GCRF) Networking Grant, awarded through the Arts and Humanities Research Council (AHRC) of Great Britain.

Ethics approval Ethics approval was granted via the Institute of Development Studies (IDS) Ethics process. The data are jointly owned by the authorial team who have given permission to publish. There are no conflicts of interest here. Data collected and shared will be stored on the IDS data system and can be made available on request.

\section{References}

Barakat, S., \& Milton, S. (2015). Houses of wisdom matter: The responsibility to protect and rebuild higher education in the Arab world. Doha: Brookings Doha Center. Retrieved 20 April 2021 from https://www.brookings.edu/wp-content/uploads/2016/06/En-Higher-Ed-Web.pdf.

Beard, C., Clegg, S., \& Smith, K. (2007). Acknowledging the affective in higher education. British Educational Research Journal, 33(2), 235-252. https://doi.org/10.1080/01411920701208415.

Bergan, S. \& Van't Land, H. (2010). Speaking across borders : the role of higher education in furthering intercultural dialogue. Strasbourg: Council of Europe. Retrieved 15 March 2021 from https://rm. coe.int/speaking-across-borders-the-role-of-higher-education-in-furthering-int/168075dddc.

Bourner, T. (1998). Bridges and towers: Action learning and personal development in higher education. Inaugural Lecture, 24 November, University of Brighton. Retrieved 15 March 2021 from https:// studylib.net/doc/7399901/action-learning-and-personal-development-in-he.

Burstyn, J. N. (2001). The challenge for schools: To prevent violence while nurturing democracy. In J. N. Burstyn, G. Bender, R. Casella, H. W. Gordon, \& D. P. Guerra (Eds.), Preventing violence in schools: A challenge to American democracy (pp. 225-234). Mahwah, NJ: Lawrence Erlbaum Associates. Joan N. Burstyn, Geoff Bender, Ronnie Casella, Howard W. Gordon, Domingo P. Guerra.

Bush, K.D., \& Saltarelli D. (2000). The two faces of education in ethnic conflict: Towards a peacebuilding education for children. Florence: UNICEF Innocenti Research Centre. Retrieved 15 March 2021 from https://www.unicef-irc.org/publications/pdf/insight4.pdf.

Carr, W., \& Hartnett, A. (1996). Education and the struggle for democracy: The politics of educational ideas. Buckingham: Open University Press.

Clarke-Habibi, S. (2018). Teachers' perspectives on educating for peace in Bosnia and Herzegovina. Journal of Peace Education, 15(2), 144-168. https://doi.org/10.1080/17400201.2018.1463209.

Davies, L. (2004). Conflict and education: Complexity and chaos. London: RoutledgeFalmer.

Davies, L. (2010). The different faces of education in conflict. Development, 53(4), 491-497. https://doi. org/10.1057/dev.2010.69.

Davies, L. (2016). Security, extremism and education: Safeguarding or surveillance? British Journal of Educational Studies, 64(1), 1-19. https://doi.org/10.1080/00071005.2015.1107022.

Davies, L. (2017). The power of a transitional justice approach to education: Post-conflict education reconstruction and transitional justice. ICTJ Studies on Education and Transitional Justice. New York: International Center for Transitional Justice (ICTJ). Retrieved 15 March 2021 from https:// www.ictj.org/publication/power-transitional-justice-approach-education.

Evans, N., Ziaian, T., Sawyer, J., \& Gillham, D. (2013). Affective learning in higher education: A regional perspective. Australian and International Journal of Rural Education, 23(1), 23-41.

Eyler, J., \& Giles, D. E., Jr. (1999). Where’” the learning in service-learning? Jossey-Bass Higher and Adult Education series. San Francisco, CA: Jossey-Bass.

Fetherston, B., \& Kelly, R. (2007). Conflict resolution and transformative pedagogy: A grounded theory research project on learning in higher education. Journal of Transformative Education, 5(3), 262285. https://doi.org/10.1177/1541344607308899.

Fitzmaurice, M. (2008). Voices from within: Teaching in higher education as a moral practice. Teaching in Higher Education, 13(3), 341-352. https://doi.org/10.1080/13562510802045386.

Francis, D. J. (2008). Peace and conflict in Africa. London: Zed Books.

Freire, P. (1970). Pedagogy of the oppressed. Translated by M. Bergman Ramos. New York: Herder and Herder.

Freire, P. (1998). Teachers as cultural workers: Letters to those who dare teach. Translated by D. Macedo, D. Koike \& A. Oliveira. Boulder, CO: Westview Press. 
Galtung, J. (1969). Violence, peace, and peace research. Journal of peace research, 6(3), 167-191. https://doi.org/10.1177/002234336900600301.

Gill, S., \& Niens, U. (2014). Education as humanisation: A theoretical review on the role of dialogic pedagogy in peacebuilding education. Compare: A Journal of Comparative and International Education, 44(1), 10-31. https://doi.org/10.1080/03057925.2013.859879.

Giroux, H. A. (2004). Cultural studies, public pedagogy, and the responsibility of intellectuals. Communication and Critical/Cultural Studies, 1(1), 59-79. https://doi.org/10.1080/1479142042000180926.

Harris, I. M. (2004). Peace education theory. Journal of Peace Education, 1(1), 5-20. https://doi.org/10. 1080/1740020032000178276.

Hussein, S.M. (2017). Performing peace empathically: The narrative turn in my name is Rachel Corrie. The Arab Journal of Performance Studies, 5, 46-63. Retrieved 15 March 2021 from https://www. academia.edu/36162052/The_Suppliants_of_Syria_Narratives_of_Displacement_and_Resettleme nt_in_Refugee_Performances_of_Greek_Tragedy.

Jones, J. R., \& Augustine, S.M. (2015). Creating an anti-bullying culture in secondary schools: Characterists $[\mathrm{sic}]$ to consider when constructing appropriate anti-bullying programs. American Secondary Education, 43(3), 73-84. https://www.jstor.org/stable/43694219.

Lederach, J. P. (2005). The moral imagination: The art and soul of building peace. New York, NY: Oxford University Press.

Millican, J. (2014a). Engaging with the other: Student community engagement and the development of citizenship after conflict. In J. Laker, C. Naval, \& K. Mrnjaus (Eds.), Citizenship, democracy and higher education in Europe, Canada and the USA (pp. 107-122). London: Palgrave Macmillan.

Millican, J. (2014b). Higher education and student engagement: implications for a new economic era. Education+Training, 56(7), 635-649. https://doi.org/10.1108/ET-07-2014-0077.

Millican, J. (Ed.). (2017). Universities and conflict: The role of higher education in peacebuilding and resistance. London: Routledge.

Millican, J., \& Bourner, T. (2014). Learning to make a difference: Student-community engagement and the higher education curricluum. Leicester: National Institute of Adult Continuing Education (NIACE).

Milton, S. (2018). Higher education, conflict causation and post conflict peacebuilding. In J. Millican (Ed.), Universities and conflict: The role of higher education in peacebuilding and resistance (pp. 44-62). London: Routledge.

Milton, S., \& Barakat, S. (2016). Higher education as the catalyst of recovery in conflict-affected societies. Globalisation, Societies and Education, 14(3), 403-421. https://doi.org/10.1080/14767724. 2015.1127749.

Mundy, K., \& Dryden-Peterson, S. (Eds.). (2011). Educating children in conflict zones: Research, policy, and practice for systemic change - a tribute to Jackie Kirk. New York: Teachers College Press.

Murithi, T. (2008). African indigenous and endogenous approaches to peace and conflict resolution. In D. J. Francis (Ed.), Peace and conflict in Africa (pp. 16-30). London: Zed Books.

Noddings, N. (2002). Educating moral people: A caring alternative to character education. New York: Teachers College Press.

Novelli, M. (2016). Capital, inequality and education in conflict-affected contexts. British Journal of Sociology of Education, 37(6), 848-860. https://doi.org/10.1080/01425692.2016.1165087.

Novelli, M., \& Cardozo, M. T. L. (2008). Conflict, education and the Global South: New critical directions. International Journal of Educational Development, 28(4), 473-488. https://doi.org/10.1016/j. ijedudev.2008.01.004.

Novelli, M., Lopes Cardozo, M.T.A., \& Smith, A. (2015). A theoretical framework for analysing the contribution of education to sustainable peacebuilding: 4Rs in conflict-affected contexts. Amsterdam: University of Amsterdam, Retrieved 15 March 2021 from https://core.ac.uk/download/pdf/30614 168.pdf.

Novelli, M. \& Smith, A. (2011). The role of education in peacebuilding. A synthesis report of findings from Lebanon, Nepal and Sierra Leone. Evaluation report. New York: United Nations Children's Fund (UNICEF). Retrieved 15 March 2021 from https://www.unicef.org/spanish/evaldatabase/files/ EEPCT_PeacebuildingSynthesisReport.pdf.

Nussbaum, M. (1997). Cultivating humanity. A classical defense of reform in liberal education. Cambridge, MA: Harvard University Press.

OECD (Organisation for Economic Co-operation and Development) (2014). Education at a Glance 2014: OECD Indicators. Paris: OECD Publishing. Retrieved 20 April 2021 from https://www.oecd.org/ education/Education-at-a-Glance-2014.pdf. 
Omeje, K. (2008). Understanding conflict resolution in Africa. In D. J. Francis (Ed.), Peace and conflict in Africa (pp. 68-91). London: Zedbooks.

Omeje, K. (2014). Peace education and peacebuilding in sub-Saharan Africa: A conflict-sensitive approach in higher education. Paper prepared for the Fourth European Congress on World and Global History: Encounters, Circulations and Conflicts, organised by the European Network in Universal and Global History (ENIUGH) in Paris, 4-7 September.

Omeje, K. (2015). Promoting peace and conflict-sensitive higher education in sub-Saharan Africa. African Conflict and Peacebuilding Review, 5(2), 33-56. https://doi.org/10.2979/africonfpeacrevi.5.2. 33.

Pacheco, I.F. \& Johnson, A.T. (2017). Global higher education conflict and postconflict conditions: Colombia and Kenya. In G. Mihut, P.G. Altbach \& H.Wit (Eds), Understanding global higher education (pp. 111-113). Rotterdam: Sense. https://doi.org/10.1007/978-94-6351-044-8_23.

Paulson, J. (2015). "Whether and how?" History education about recent and ongoing conflict: A review of research. Journal on Education in Emergencies, 1(1), 115-141. https://doi.org/10.17609/N84H20.

Pherali, T. (2019). Education and conflict: Emergence, growth and diversification of the field. Education and Conflict Review, 2, 7-14.

Pickus, N., \& Reuben, J. A. (2010). Debating moral education: Rethinking the role of the modern university. Durham, NC: Duke University Press.

Richmond, O. P. (2011). A post-liberal peace. London: Routledge.

Rorty, R. (1998). Human rights, rationality, and sentimentality In R. Rorty Truth and progress: Philosophical papers (pp. 167-185). Cambridge: Cambridge University Press. https://doi.org/10.1017/ CBO9780511625404.010.

Roser, M., \& Ortiz-Ospina, E. (2016). Global education [online article]. Oxford: Our World in Data, Global Change Data Lab. Retrieved 16 March 2021 from https://ourworldindata.org/global-rise-ofeducation.

Schön, D. (1987). Educating the reflective practitioner: Toward a new design for teaching and learning in the professions. Jossey-Bass higher education series. San Francisco, CA: Jossey-Bass.

Shephard, K. (2008). Higher education for sustainability: Seeking affective learning outcomes. International Journal of Sustainability in Higher Education, 9(1), 87-98. https://doi.org/10.1108/14676 370810842201 .

Staub, E. (2002). From healing past wounds to the development of inclusive caring: Contents and processes of peace education. In G. Salomon \& B. Nevo (Eds.), Peace Education: The concept, principles, and practices around the world (pp. 73-86). Mahwah, NJ: Lawrence Erlbaum Associates.

Stiasny, M., \& Gore, T. (Eds.). (2014). Global Education: Knowledge-based economies for the $21 \mathrm{~s}^{t}$ century. Papers from the British Council's Going Global 2013 Conference. Bingley: Emerald Group Publishing.

UN (United Nations) (1995). General framework agreement for peace in Bosnia and Herzegovina. A/50/790 S/1995/999. Dayton, OH/Paris: United Nations General Assembly Security Council. Retrieved 16 March 2021 from https://peacemaker.un.org/bosniadaytonagreement 95.

UNESCO (United Nations Educational Scientific and Cultural Organization) (2017). Six ways to ensure higher education leaves no one behind. Policy paper no. 30. Paris: UNESCO International Institute for Educational Planning. Retrieved 16 March 2021 from https://unesdoc.unesco.org/ark:/48223/ pf0000247862.

Wagoner, B., \& Brescó, I. (2016). Conflict and memory: The past in the present. Peace and Conflict: Journal of Peace Psychology, 22(1), 3-4. https://doi.org/10.1037/pac0000147.

Webel, C., \& Galtung, J. (2007). Handbook of peace and conflict studies. London: Routledge.

Whitaker, E. (2020). Unpublished presentation as part of a webinar on Climate Change and Conflict hosted by the Department for International Development (DfID) on 24 March 2020.

Zlotkowski, E. (2007). The case for service learning. In L. McIlrath \& I. MacLabhrainn (Eds.), Higher education and civic engagement: International perspectives (pp. 37-52). Aldershot: Ashgate.

Publisher's Note Springer Nature remains neutral with regard to jurisdictional claims in published maps and institutional affiliations.

Juliet Millican $\mathrm{PhD}$, holds a doctorate in Education and Conflict that focused on the role of higher 
education in post-conflict Bosnia and Herzegovina. She is currently an associate research fellow at the Institute of Development Studies in the UK and works as an independent consultant in the fields of education, peacebuilding and regenerative humanitarian response. Her recent publications include Universities and Conflict: The Role of Higher Education in Peacebuilding and Resistance (Routledge 2018) and Gardening in displacement: The benefits of cultivating in crisis, Journal of Refugee Studies, 32(3), 351-371 (2019).

Larisa Kasumagić-Kafedžić $\mathrm{PhD}$ is an associate professor in the Faculty of Philosophy at the University of Sarajevo, where she teaches within the field of teacher education, critical pedagogy, peace and intercultural pedagogies in foreign language and culture didactics. She has been actively involved in community youth development, peace and non-violence, and intercultural pedagogy for the past 25 years. She holds an MA in International Development and Education from Cornell University, USA, where her research focused post-war healing, and a PhD in English Language Pedagogy and Intercultural Education from the University of Sarajevo. She publishes on teacher education and post-war healing.

François Masabo $\mathrm{PhD}$, holds a doctorate in social sciences with a specialisation in the Sociology of change and conflict. He is a researcher at the Centre for Conflict Management (CCM) at the University of Rwanda. His own research interests are mainly focused on conflict transformation processes, genocide memories and post-conflict reconstruction challenges. Some of his recent publications are: Healing fractured lives: Reconciliation and reintegration in Rwanda, (co-authored with Aurélien Tobie, International Alert 2012); Role of civil society organizations in conflict and post-conflict situations in Rwanda, Journal of African Conflicts and Peace Studies, 3(2), 16-37 (2017); and Transforming conflict in a post genocide society: An evaluation of the one cow per family programme in Rwanda (publication under way).

Mónica Almanza is currently a researcher at the Center for Applied Ethics at Universidad de los Andes in Colombia, working professionally in Literary Studies, and studying for a $\mathrm{PhD}$ in Education. She is co-founder of the Ethics and Citizenship Education Network (REDETICA in Spanish). Her educational research areas are ethics, memory, conflict and peace, especially in higher education. 